\title{
Protein-Losing Gastroenteropathy and Gastric Polyps: Successful Treatment by Helicobacter pylori Eradication
}

\author{
Takamitsu Sato Gaku Chiguchi Masahiko Inamori Hitomi Sakai Nobutaka Fujisawa \\ Tomoyuki Akiyama Keiko Akimoto Koji Fujita Hirokazu Takahashi Masato Yoneda \\ Yasunobu Abe Kensuke Kubota Norio Ueno Atsushi Nakajima \\ Gastroenterology Division, Yokohama City University School of Medicine, Yokohama, Japan
}

\section{Dear Sir,}

Protein-losing gastroenteropathy is a disease associated with excessive loss of plasma protein into the gastrointestinal tract and is caused by a wide variety of disorders. A 71-year-old man was admitted to our hospital for edema and body weight loss. His serum total protein level was 4.2 $\mathrm{g} / \mathrm{dl}$, and the albumin concentration was $2.6 \mathrm{~g} / \mathrm{dl}$. Endoscopy of the upper gastrointestinal tract showed a lot of reddish pedunculated polyps, measuring 5-20 mm in diameter, in gastric body and antrum (fig. 1). Histological investigation of biopsy specimens revealed hyperplastic changes, and Helicobacter pylori was confirmed. His $\alpha_{1}$-antitrypsin clearance was $120 \mathrm{ml} /$ day, and he was diagnosed as having protein-losing gastroenteropathy. We tried $H$. pylori eradication therapy for reduction of the polyps. After 1 month, an urea breath test revealed that $H$. pylori had been eradicated from his stomach. Two months after $H$. pylori eradication therapy, endoscopic examination showed that the gastric polyps were smaller in size. His body weight increased, and the serum total protein level also increased to $5.8 \mathrm{~g} / \mathrm{dl}$ and the albumin concentration to $3.8 \mathrm{~g} / \mathrm{dl}$. We succeeded in treating protein-losing gastroenteropathy associated with gastric hyperplastic polyps by $H$. pylori eradication.

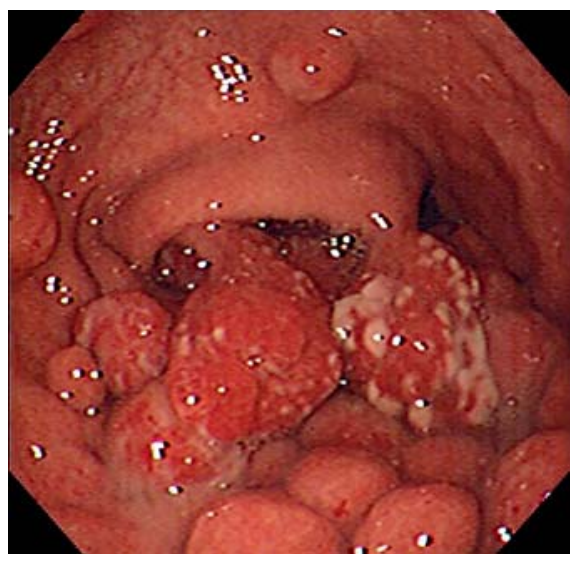

Fig. 1. Endoscopic upper gastrointestinal tract appearance before $H$. pylori eradication. Reddish pedunculated polyps are seen, some of which have an irregular surface and a spotty white coating.

\section{KARGER}

Fax +41613061234 E-Mail karger@karger.ch www.karger.com
Masahiko Inamori

Yokohama City University, Gastroenterology Division

3-9, Fukuura, Kanazawa-ku

Yokohama, Kanagawa 236-0004 (Japan)

Tel. +81 45787 2640, Fax +81 45784 3546, E-Mail inamorim@med.yokohama-cu.ac.jp 